\title{
Preliminary study for non - invasive optical detection of squamous and basal cell carcinomas
}

\author{
Ahmed Mohammed Ali ${ }^{1 *}$, Munqith Saleem Dawood ${ }^{1}$, Mohammed Kadhim Taher ${ }^{2}$ and Faeza Aftan Zghair ${ }^{1}$
}

\footnotetext{
* Correspondence:

ahmed_mohammed381@yahoo. com

${ }^{1}$ College of Engineering, Medical Engineering Department, Al-Nahrain University, Baghdad, Iraq Full list of author information is available at the end of the article
}

\begin{abstract}
Background: The early detection of skin cancer may highly increase the chances of its healing. One of the non-invasive methods of such detection based on the Oblique- Incidence Diffuse Reflectance (OIDR) measurements of the reflected diode laser light from the skin. In this research we designed and implemented the OIDR reflectometry measuring system with a $650 \mathrm{~nm}$ diode laser source to aid physicians in diagnosing both squamous cell carcinomas (SCC) and basal cell carcinomas(BCC).

Method: The laser is delivered obliquely to the skin surface by an optical fiber fitted through a tube holder of CCD camera. The diffused reflected laser light from the skin is captured by the CCD camera and sent to a computer, which is supplied by a specially prepared Matlab program to analyze these images in order to decide in a time whether the lesion is malignant or benign. Fifty cases were diagnosed under supervision of the consultant section of The Governmental Specialized Marjan Teaching Hospital - $\mathrm{MOH}$ - Iraq.

Result: The fifty diagnosed cases by this technique, the results were $90 \%$ accurate.

Conclusion: The method of laser oblique-incidence diffuse reflectance (OIDR) combined with using the developed algorithms that have high classification rates may prove useful in the clinic as the process is fast, noninvasive and accurate.

Keyword: Skin cancer detection, Diffusion theory, Oblique incidence diffuse reflectance, Reflectometry
\end{abstract}

\section{Introduction}

Skin cancer is the most common form of cancers with increasing rate per year especially in fair skin population. Non-melanoma skin cancers account for about half of all cancers and include basal cell carcinomas (BCC) and squamous cell carcinomas (SCC) [1]. "Current diagnostic methods for skin cancers rely on physical examination of lesions in conjunction with skin biopsy, which involves the removal of tissue samples from the body for examination. Biopsy of large lesions often requires substantial tissue removal. Though this protocol for skin lesion diagnosis has been accepted as the golden standard, it is subjective, invasive, time-consuming and painful. Laboratory results for the determination of histopathology of a suspected tumor may generally take several days. Since suspicious areas are identified by visual inspection alone, there are a significant number of false positives that undergo biopsy. Conversely, many malignant lesions can also be overlooked. There is an urgent need for objective criteria that would aid the clinician in evaluating whether biopsy is required" [2].

(c) 2012 Mohammed et al.; licensee BioMed Central Ltd. This is an Open Access article distributed under the terms of the Creative Commons Attribution License (http://creativecommons.org/licenses/by/2.0), which permits unrestricted use, distribution, and reproduction in any medium, provided the original work is properly cited. 
Now a days there is a growing demand for accurate and fast models to predict the light distribution in biological tissues to deduce their optical properties from the measurable quantities [3]. One of the measurable quantities is the diffuse reflectance, it is a function of the distance between the observation point and the incident point of a laser beam. The diffuse reflectance is defined as the photon probability of re-emission from inside a semiinfinite turbid medium per unit surface area (skin tissue). Measurements of the diffuse reflectance can be used to determine the optical properties of tissue non-invasively [3].

Biological scatterers are primarily cell nuclei and mitochondria, with diameters ranging from $1 \mu \mathrm{m}$ to $8 \mu \mathrm{m}$. As the laser light wavelength is smaller than these scatterers, therefore the light interaction can be predicted by Mie scattering theory, which is an exact analytical solution of Maxwell's electromagnetic field equations, but when the scattering particles are much smaller than the wavelength, the light interaction can be predicted by Raleigh scattering theory, which is a limiting case of Mie theory. Scattering coefficient is defined as the probability of photon scattering per unit infinitesimal path length [4].

In this paper we present a design and implementation of a non-invasive, painless and fast method to deduce the optical properties of skin cancerous suspicion lesions based on the application of the oblique incidence diffused reflectance reflectometry (OIDR) as originally conceived by Wang and Jacques $[5,6]$.

The images of the diffused reflectance for both lesion and healthy adjacent skins of the same patient are captured by a CCD camera, these images are then analyzed and processed by a specially written Matlab program v.10 to perform a logical prediction (diagnosis) for the examined lesion for squamous and basal cancerous cells.

\section{Materials and methods}

\section{Patients studied}

SCC and BCC are types of non-melanoma skin cancer that chosen by Research Section of Medical Engineering / College of Engineering / Al-Nahrain University.

Fifty patients are selected under supervision of Dermatology Consultant Section of The Governmental Marjan Teaching Hospital / MOH - Iraq. Dermatologist identify suspicious skin lesion that were going to be biopsied for routine care. Patients were asked to participate in the study and sign on informed consent approved by the Babylon Health Directorate / $\mathrm{MOH}$ - Iraq.

The needed data from each patient were collected, analyzed and recorded before physicians removed the lesion and sent it for biopsy. Histopathological diagnoses was performed by the specialized laboratory of Marjan Teaching Hospital and reported within 6 to 7 days to compare with our recorded logic predicted result.

\section{Oblique incidence diffused reflectance method}

The significant changes that happen in malignant cells make it optically differentiable from benign cells due to the enlargement in their cell nuclei and mitochondria sizes, it is important to know that the nuclei and mitochondria are the major scatterers in the cells, therefore the enlargement of their size considered as the important indicator to the presence of cancer cells that cause increase in light scattering $[4,7]$. 
When a light enters a semi-infinite tissue, it will generally scatter many times before either being absorbed or escaping the tissue surface at a point other than its point of entry. The multiple scattered light that escapes is called diffuse reflectance $[8,9]$, as seen in Figure 1.

Because it is easier to model isotropic scattering than anisotropic scattering, the reduced or transport scattering coefficient $\mu_{\mathrm{s}}^{\prime}$ is introduced as the equivalent isotropic scattering coefficient of an anisotropically scattering medium. $\mu_{\mathrm{s}}{ }^{\prime}=\mu_{\mathrm{s}}(1-\mathrm{g})$, where $\mu_{\mathrm{s}}$ is the scattering coefficient and $g$ is the average cosine of the scattering angle $[8,11]$ :

A sketch for the laser oblique incidence diffuse reflectance pattern from a semi-infinite turbid medium like the biological tissue is shown in Figure 2.

The spatial distribution of diffuse reflectance of an oblique incident laser beam from a semi-infinite turbid medium like the biological tissue has been modeled according to Wang and Jacques by two isotropic point sources; one positive source located below the tissue surface and one negative image source above the tissue surface, as shown in Figure 3. The positive source is buried at distance $\left(d_{s}\right)$ from the point of laser incidence on the skin, this distance is considered practically to be three times greater than the diffusion coefficient " $\mathrm{D}$ " as in the mean free path Eq.(1) $[6,11,12]$ :

$$
1 m e f=d_{s}=3 D=\frac{1}{0.35 \mu_{a}+\mu_{s}^{\prime}}
$$

The modified dipole source diffusion theory model gives diffuse reflectance at the skin boundary $\mathrm{R}(\mathrm{x})$, by using Eq.(2) which can be scaled to fit a relative reflectance profile that is in absolute units [6].

$$
R(x)=\frac{1}{4 \pi}\left[\frac{\Delta z\left(1+\mu_{\text {eff }} \rho_{1}\right)}{\rho_{1}^{3}}+\frac{\left(\Delta z+2 z_{b}\right)\left(1+\mu_{\text {eff }} \rho_{2}\right) \exp \left(-\mu_{\text {eff }} \rho_{2}\right)}{\rho_{2}^{3}}\right]
$$

Where ;

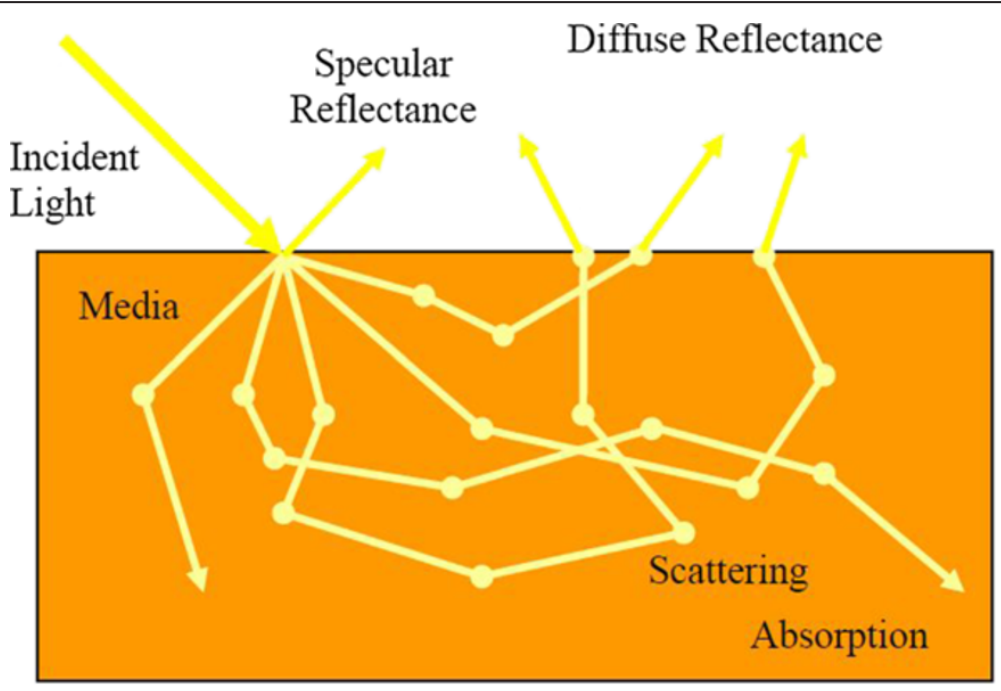

Figure 1 Light interaction in a scattering and absorbing media [10]. 


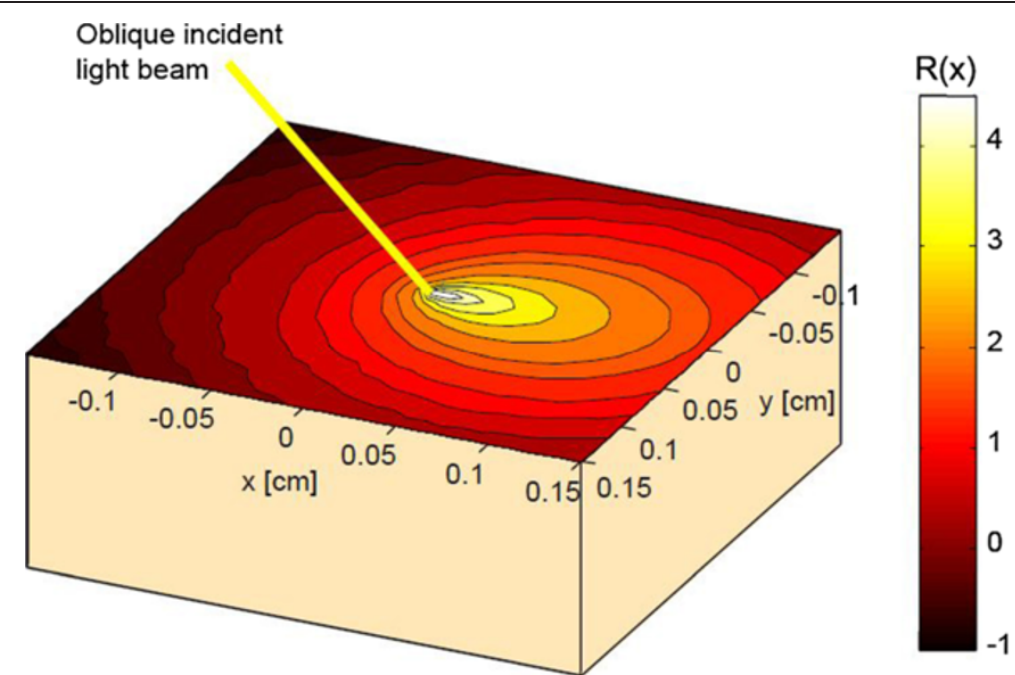

Figure 2 Single wavelength oblique incidence diffuse reflectance pattern [10].

$\alpha_{\mathrm{i}}$ : is the angle between the incident laser beam and the normal line on the tissue surface.

$\alpha_{t}$ : is the angle of light transmission into the tissue, could be calculated according to Snell's law which is used to measure the new optical path where the isotropic positive point is locate. as seen in Figure 3.

$\mathrm{r}:$ is the distance between the normal line between the positive and negative point and the observation point.

$x:$ is the distance between the point of observation and the point of light incidence (origin point).

$\rho_{1}, \rho_{2}$ : are the distances from the two point sources to the point of interest.

$\mathrm{z}_{\mathrm{b}}$ : is the distance between the virtual boundary and the surface of the tissue.

$A$ : is the parameter related to the internal reflection which can be calculated using either Fresnel reflection coefficients or using empirical variable $r_{i}$ and relative reflection coefficient $n_{\text {rel }}$ of the tissue ambient (air) interface as following [8]:

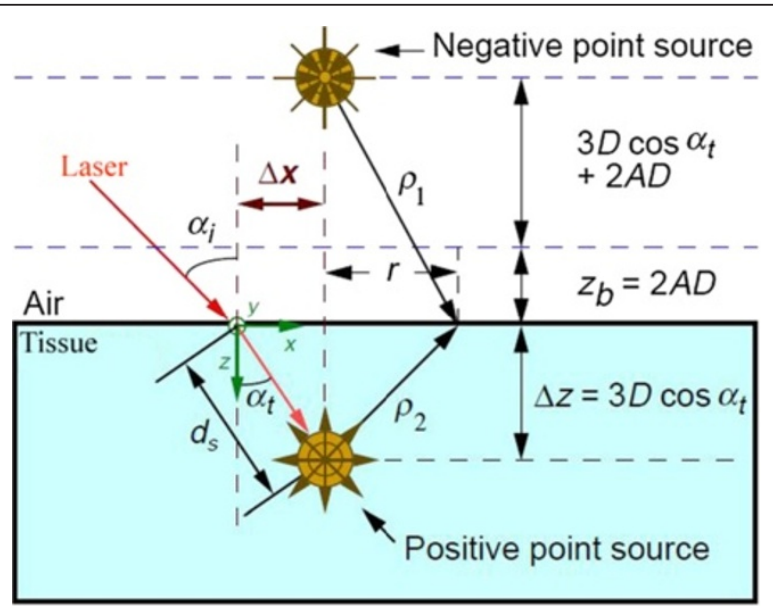

Figure 3 Schematic representation of obliquely incident light [6]. 


$$
\begin{aligned}
& n_{r e l}=n_{\text {tissue }} / n_{\text {ambint }} \\
& r_{i}=-1.440 n_{\text {rel }}^{-2}+0.710 n_{r e l}^{-1}+0.668+0.0636 n_{r e l} \\
& A=\frac{1+r_{i}}{1-r_{i}}
\end{aligned}
$$

$A$ : is unity for a matched boundary [8].

$\Delta z:$ is the depth of the positive point source from the surface of skin.

$$
\Delta z=\frac{\cos \left(a_{t}\right)}{\mu_{a}+\mu_{s}^{\prime}}=\Delta x \tan ^{-1}\left(a_{t}\right)
$$

$\Delta \mathrm{x}$ : is the distance shift between the point of laser incidence and the center of the most symmetrical circle, as seen in Figures 2, 3 and 4.

$$
\Delta x=\frac{\sin a_{t}}{0.35 \mu_{a}+\mu_{s}^{\prime}}
$$

Ones the distance shift $(\Delta \mathrm{x})$ was found, the diffusion coefficient $\mathrm{D}$ could be calculated from Eq.(8) [6]:

$$
D=\frac{\Delta x}{3 \sin \left(a_{t}\right)}
$$

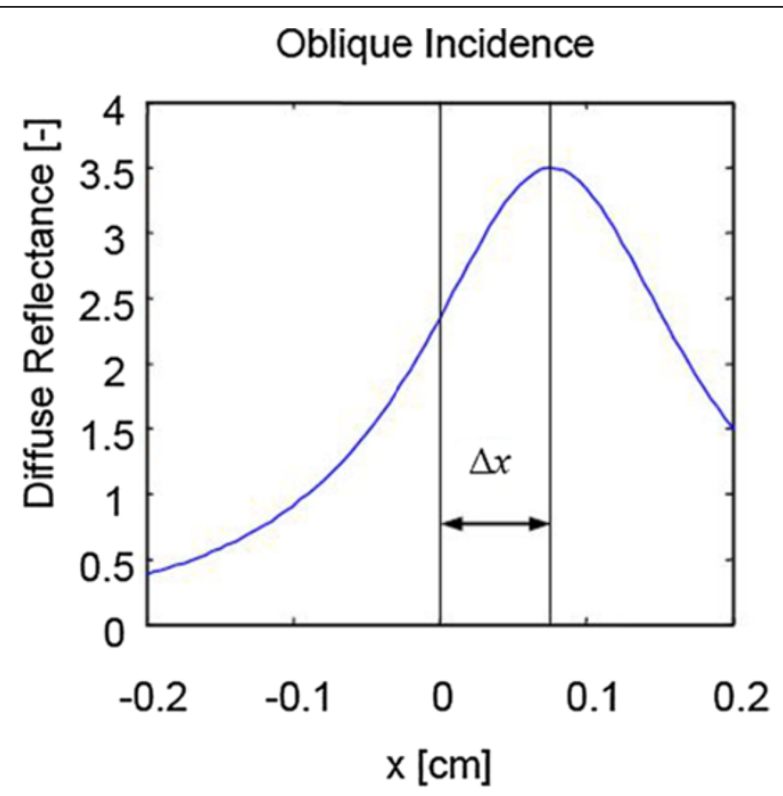

Figure 4 Oblique incidence diffuse reflectance curve along the $x$ direction [10]. 
$\mu_{\text {eff }}$ is the effective attenuation coefficient [6]:

$$
\mu_{\text {eff }}=\sqrt{\frac{\mu_{a}}{D}}
$$

The $\mu_{\text {eff }}$ value could be found by using a least-square fitting to Eq.(2).

Now it is possible to find the skin optical properties $\mu_{\mathrm{s}}{ }^{\prime}$ and $\mu_{\mathrm{a}}$ from Eqs.(10 and 11) as following [6] :

$$
\mu_{a}=\frac{\mu_{e f f}^{2} * \Delta \mathbf{x}}{3 \sin \left(a_{t}\right)}
$$

and

$$
\mu_{s}^{\prime}=\frac{\sin \left(a_{t}\right)}{\Delta x}-0.35 * \mu_{\mathrm{a}}
$$

\section{Experimental work}

\section{Experimental setup}

The oblique incidence diffused reflectance reflectometry (OIDR) system that is designed in this work to measure the skin optical properties is sketched in Figure 5. It includes the following components:

1. $650 \mathrm{~nm}$ laser diode continuous source, DILAS diode laser company.

2. Multimode fiber optic of $0.22 \mathrm{NA}$ and $200 \mu \mathrm{m}$ in diameter, fitted by a guiding needle at $45^{\circ}$ angle with the central normal imaginary line of CCD camera.

3. Charge coupled device (CCD) camera, model F-068D / Delon.

4. Computer with special written analytical Matlab program v.10.

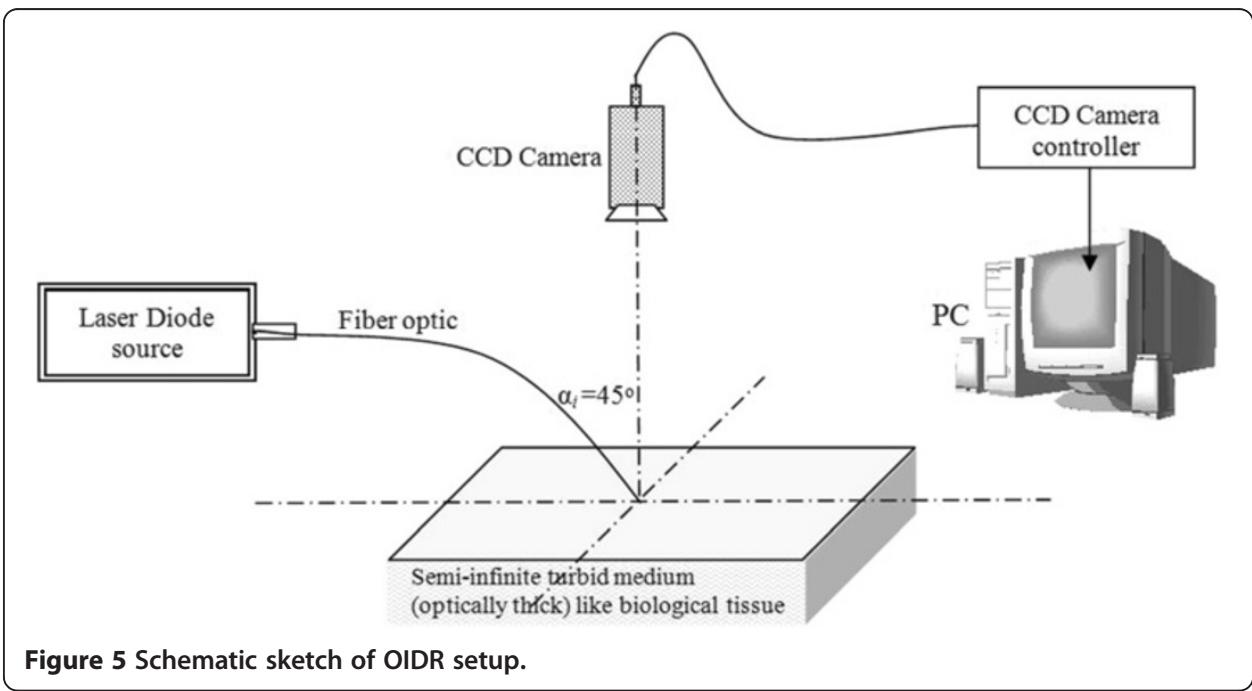




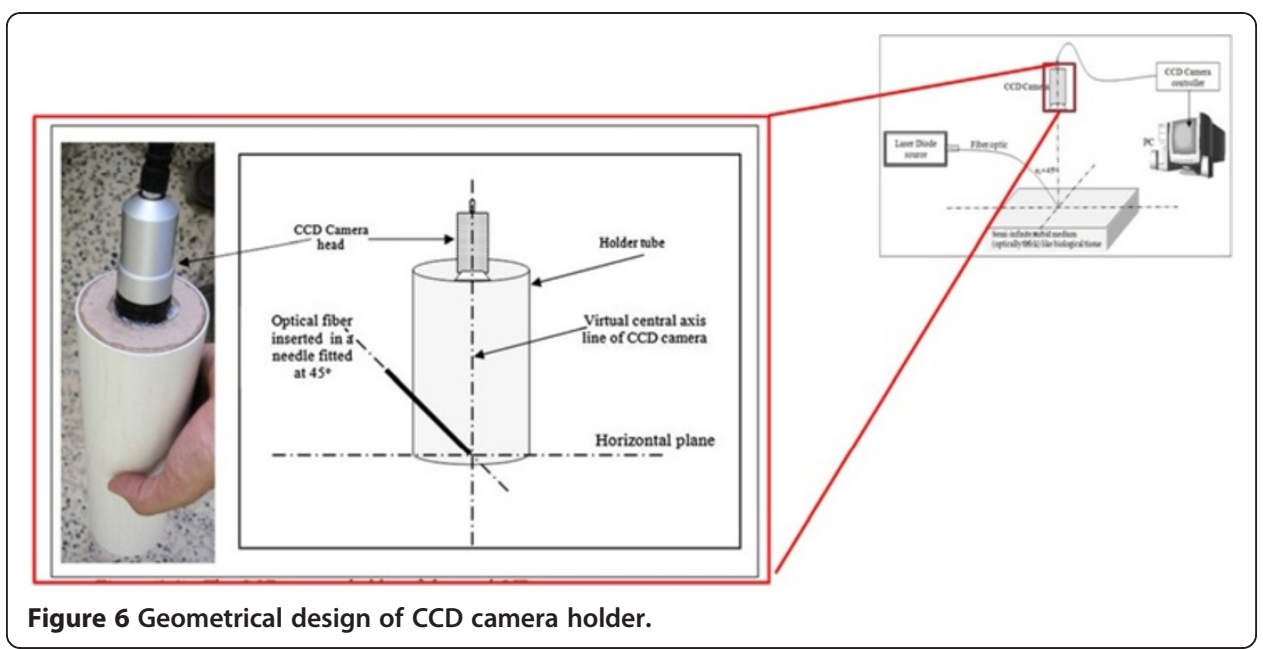

The design of CCD camera holder is shown in Figure 6. The virtual center line (axis) of CCD camera was fitted particularly to be on the center of the horizontal plane, exactly at intersecting point with the needle tip.

The CCD camera holder was painted by black color to reduce the effect of the outside light. The clinic lights were turned off during the examination. All the apparatus were placed on a small portable hospital cart as shown in Figure 7 to move it easily in the patient examination room.

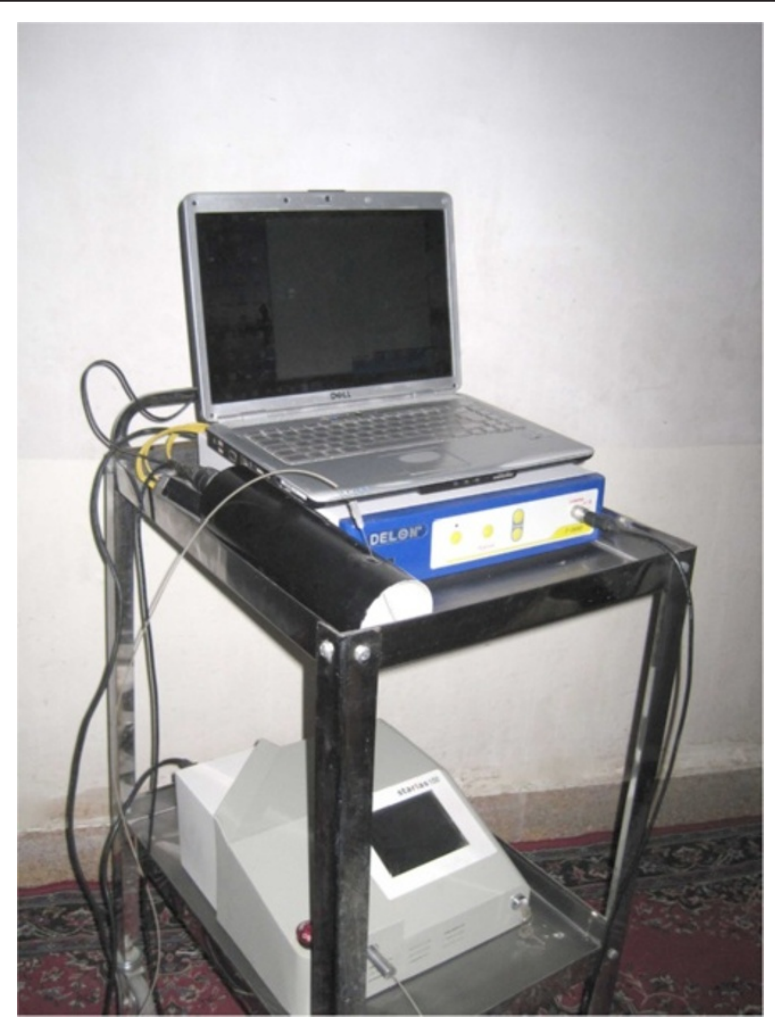

Figure 7 The implemented OIR laser system for skin cancerous examination. 


\section{Work procedure}

The lesion and adjacent healthy area were identified and marked by the dermatologist visually with aid of special lenses.

Placing the special holder tube, Figure 6, on the lesion (without pressing) then using the "c" character on the computer keyboard five times to capture five diffused reflected profile images for the suspension lesion while continuously running the laser, this procedure takes about three seconds. Then we repeat this procedure for the adjacent healthy area.

By using "c" character ( capture command ) on the keyboard the computer will collect the raw data from the $\mathrm{CCD}$ camera and import it directly to Matlab program directory folder for analysis.

The measurements are repeated five times in order to average the optical properties for each of lesion and healthy skin.

The optical examination for skin cancer diagnosis was carried on by the sequence shown in Figure 8.

Figure 9A shows a sample of the diffused reflected image of case no. 08 in Table 1, it was a low grade malignancy cancer, its relative diffused reflectance curve resulted by the Matlab program computations is shown in Figure 9B.

For the same patient case no. 08 in Table 1, Figures 9C and 9D show the diffuse reflected image of the healthy adjacent skin area and its relative diffused reflectance curve resulted by the Matlab program computations respectively.

\section{Results and discussion}

The results are tabulated for fifty examined cases presented in Table 1. Our experimental non-invasive logical prediction decision, beside the invasive biopsy analysis result is shown in the table as well as the optical parameters of the lesion and the healthy skins for each patient. Figures 10 and 11 show the optical properties of the all fifty cases.

This OIDR setup required at least 8 bit of dynamic range of CCD camera to measure the diffuse reflectance within a few centimeters radius of diffused reflectance image, without bring the CCD camera in saturation state.

The accuracy of $\Delta \mathrm{x}$ shift value measurement was proportional to the resolution of the CCD camera in the setup. In our study, the size of pixel was $0.05 \mathrm{~mm} /$ pixel and the CCD camera dynamic range was 16 bit.

The sharpness and $\Delta \mathrm{x}$ measurement accuracy of the diffused reflected images, as were shown in Figures 9A and 9C, increased after painting the camera holder tube black.

The $620-670 \mathrm{~nm}$ visible light range is better for these applications than the UV and IR. A red $650 \mathrm{~nm}$ diode laser was selected for these measurements due to its low absorption in the high scattering epidermal tissue, which increased the accuracy of the measured optical properties. While using a green laser of $532 \mathrm{~nm}$ wavelength to check this phenomena shows that the reflectance at $532 \mathrm{~nm}$ was below the sensitivity of the CCD camera system.

The diagnostic logical decisions in Table 1 was based on the $\mu_{\mathrm{s}}^{\prime}$ threshold value selection beside the increment in the $\mu_{\mathrm{a}}$ value, Figure 12 shows the decision rule flow chart for the 50 patients. If the difference value between the scattering coefficient of lesion and the scattering coefficient of healthy adjacent skin greater than or equal to $1.8 \mathrm{~cm}^{-1}$ 


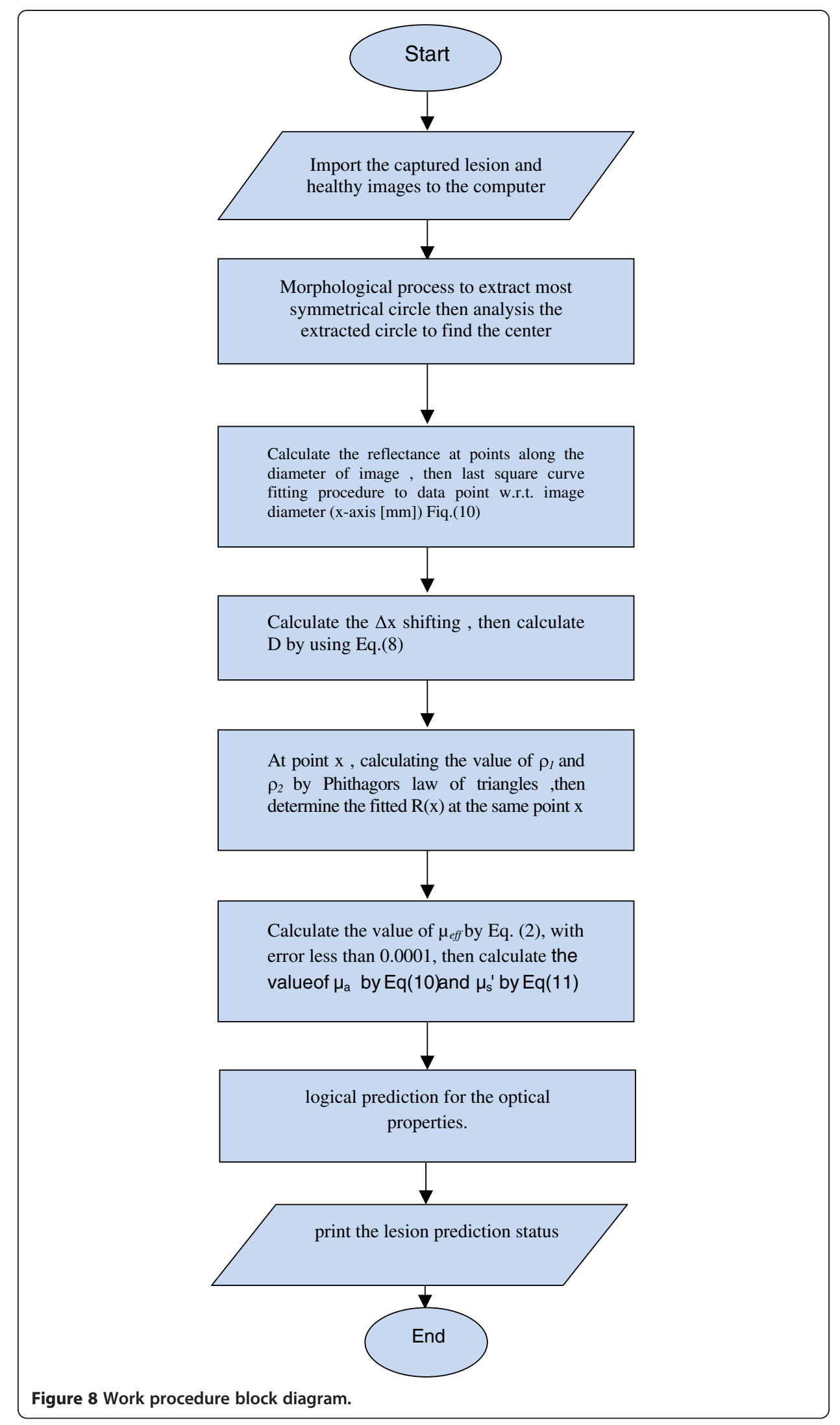




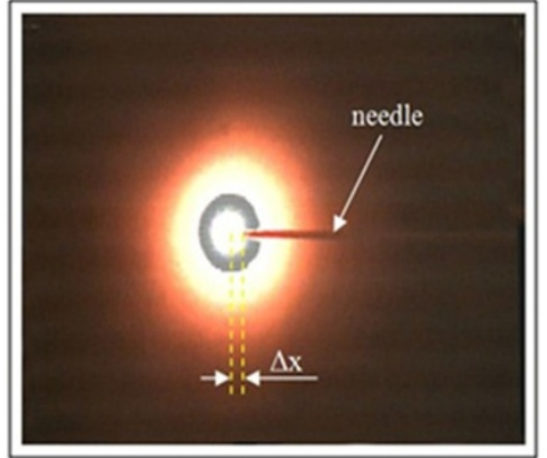

A : Diffused reflected image of lesion of case no. 08 in table(1).

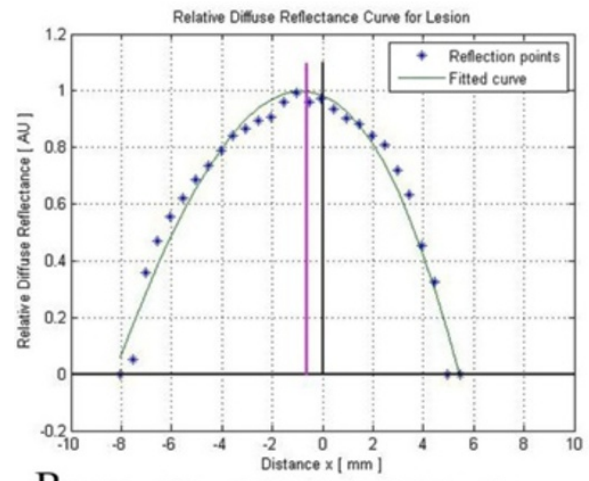

B: Relative diffuse reflectance curve for lesion of case no. 08 in table(1).

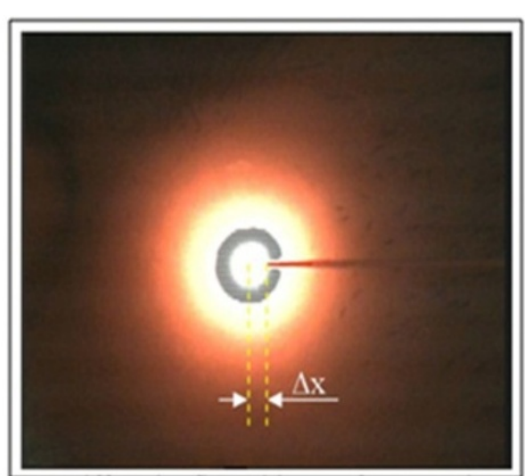

C: Diffused reflected image of the healthy adjacent skin area of case no. 08 in table(1).

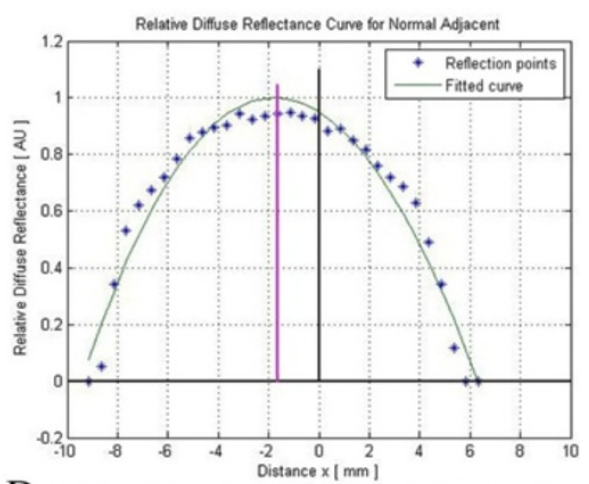

D : Relative diffuse reflectance curve for healthy skin of case 08 in table(1).

Figure 9 Diffused reflected images for both lesion and healthy adjacent skin area, with their relative diffuse reflectance curves of case no. 08 in Table 1.

and less than or equal to $4 \mathrm{~cm}^{-1}$ and combined with a small increment in the absorption coefficient of lesion over the absorption coefficient of normal healthy adjacent skin, then this lesion will be considered as a low grade malignancy lesion case.

The threshold value $\left(1.8 \mathrm{~cm}^{-1}\right)$ was chosen according to case no. (09) in Table 1, which is of a 35 year male with lesion in the cheek. The biopsy result was low grade malignant and the difference between the reduced scattering coefficient of lesion and adjacent healthy skin was $1.8511 \mathrm{~cm}^{-1}$.

While, the threshold value $4 \mathrm{~cm}^{-1}$ was chosen according to case no. (15) in Table 1, 47 year female with lesion in the cheek, the biopsy result was low grade malignant and the difference between the reduced scattering coefficient of lesion and normal healthy adjacent skin was $3.9608 \mathrm{~cm}^{-1}$.

Therefore, the low grade malignancy threshold considered to be ranged from $1.8 \mathrm{~cm}^{-1}$ to $4 \mathrm{~cm}^{-1}$.

If the difference value between the scattering coefficient of lesion and the scattering coefficient of healthy adjacent skin less than $1.8 \mathrm{~cm}^{-1}$ and combined with a small increment in the absorption coefficient of lesion over the absorption coefficient of normal healthy adjacent skin, then this lesion will be considered as a benign lesion case.

If the difference value between the scattering coefficient of lesion and the scattering coefficient of healthy adjacent skin greater than $4 \mathrm{~cm}^{-1}$ and combined with a small 
Table 1 Results of the $\mathbf{5 0}$ cases

\begin{tabular}{|c|c|c|c|c|c|c|c|c|c|}
\hline \multirow[t]{2}{*}{ Case No } & \multicolumn{2}{|c|}{$\begin{array}{l}\text { Patient age } \\
\text { and Gender }\end{array}$} & \multirow[t]{2}{*}{ Lesion site } & \multicolumn{2}{|c|}{$\begin{array}{l}\text { Skin lesion } \\
\text { optical } \\
\text { parameters }\end{array}$} & \multicolumn{2}{|c|}{$\begin{array}{c}\text { Healthy } \\
\text { adjacent skin } \\
\text { optical } \\
\text { parameters }\end{array}$} & \multirow[t]{2}{*}{$\begin{array}{l}\text { Matlab } \\
\text { logical } \\
\text { prediction }\end{array}$} & \multirow[t]{2}{*}{$\begin{array}{l}\text { Histological } \\
\text { diagnosis } \\
\text { (biopsy } \\
\text { results ) }\end{array}$} \\
\hline & Gender & $\overline{\text { Age }}$ & & $\begin{array}{c}\mu_{\mathrm{s}}^{\prime} \\
{\left[\mathrm{cm}^{-1}\right]}\end{array}$ & $\underset{\left[\mathrm{cm}^{-1}\right]}{\mu_{\mathrm{a}}}$ & $\begin{array}{c}\mu_{\mathrm{s}}^{\prime} \\
{\left[\mathrm{cm}^{-1}\right]}\end{array}$ & $\underset{\left[\mathrm{cm}^{-1}\right]}{\mu_{\mathrm{a}}}$ & & \\
\hline 1 & Female & 30 & Cheek & 6.1033 & 0.4132 & 2.5565 & 0.0013 & $\begin{array}{l}\text { Low grade } \\
\text { Malignancy }\end{array}$ & SCC \\
\hline 2 & Female & 45 & Breast & 4.9191 & 0.2588 & 3.0221 & 0.0011 & $\begin{array}{l}\text { Low grade } \\
\text { Malignancy }\end{array}$ & SCC \\
\hline 3 & Male & 60 & Cheek & 20.1398 & 0.4108 & 2.1211 & 0.0016 & Malignant & SCC \\
\hline 4 & Male & 65 & Cheek & 40.4127 & 0.2058 & 3.1488 & 0.147 & Malignant & $\mathrm{BCC}$ \\
\hline 5 & Male & 53 & Cheek & 19.3786 & 0.4267 & 3.2852 & 0.1208 & Malignant & $\mathrm{BCC}$ \\
\hline 6 & Male & 72 & Cheek & 13.9541 & 0.5949 & 2.0975 & 0.0016 & Malignant & $\mathrm{BCC}$ \\
\hline 7 & Male & 42 & Cheek & 2.0559 & 0.0603 & 2.3434 & 0.0014 & Benign & Benign \\
\hline 8 & Male & 46 & Cheek & 5.787 & 0.3832 & 3.5257 & 0.1475 & $\begin{array}{l}\text { Low grade } \\
\text { Malignancy }\end{array}$ & SCC \\
\hline 9 & Male & 35 & Cheek & 5.4704 & 0.3384 & 3.6193 & 0.163 & $\begin{array}{l}\text { Low grade } \\
\text { Malignancy }\end{array}$ & SCC \\
\hline 10 & Male & 40 & Leg & 4.6936 & 0.2308 & 3.9528 & 0.1708 & Benign & Benign \\
\hline 11 & Male & 32 & Shoulder & 10.0599 & 0.8058 & 3.1776 & 0.1181 & Malignant & SCC \\
\hline 12 & Male & 53 & Cheek & 12.453 & 0.857 & 2.9346 & 0.2001 & Malignant & SCC \\
\hline 13 & Male & 36 & Chest & 3.9242 & 0.8634 & 2.0341 & 0.0321 & $\begin{array}{l}\text { Low grade } \\
\text { Malignancy }\end{array}$ & Benign \\
\hline 14 & Male & 48 & Cheek & 7.963 & 0.1765 & 2.9361 & 0.1451 & Malignant & SCC \\
\hline 15 & Female & 47 & Cheek & 6.5169 & 0.6583 & 2.5561 & 0.1239 & $\begin{array}{l}\text { Low grade } \\
\text { Malignancy }\end{array}$ & SCC \\
\hline 16 & Male & 43 & Cheek & 4.3421 & 0.6342 & 2.3692 & 0.0056 & $\begin{array}{l}\text { Low grade } \\
\text { Malignancy }\end{array}$ & Benign \\
\hline 17 & Male & 38 & Cheek & 7.5231 & 0.3541 & 3.4321 & 0.0239 & Malignant & SCC \\
\hline 18 & Male & 58 & Cheek & 5.0145 & 0.8001 & 3.0189 & 0.0098 & $\begin{array}{l}\text { Low grade } \\
\text { Malignancy }\end{array}$ & Benign \\
\hline 19 & Male & 40 & Cheek & 12.341 & 0.4271 & 3.0341 & 0.0785 & Malignant & $\mathrm{BCC}$ \\
\hline 20 & Male & 46 & Cheek & 12.4521 & 0.8765 & 3.1452 & 0.0231 & Malignant & $\mathrm{BCC}$ \\
\hline 21 & Male & 48 & Chest & 11.349 & 0.5023 & 3.0231 & 0.1228 & Malignant & SCC \\
\hline 22 & Female & 45 & Cheek & 10.7432 & 0.3923 & 2.9313 & 0.3817 & Malignant & $\mathrm{BCC}$ \\
\hline 23 & Male & 39 & Shoulder & 3.7213 & 0.2301 & 2.9736 & 0.2001 & Benign & Benign \\
\hline 24 & Male & 51 & Cheek & 5.8123 & 0.0969 & 2.3847 & 0.0185 & $\begin{array}{l}\text { Low grade } \\
\text { Malignancy }\end{array}$ & SCC \\
\hline 25 & Male & 35 & Cheek & 9.1723 & 0.7453 & 2.8376 & 0.2387 & Malignant & SCC \\
\hline 26 & Female & 46 & Cheek & 11.3729 & 0.813 & 3.0062 & 0.1078 & Malignant & $\mathrm{BCC}$ \\
\hline 27 & Male & 42 & Cheek & 3.6791 & 0.2338 & 2.4312 & 0.0132 & Benign & Benign \\
\hline 28 & Male & 54 & Chest & 3.9183 & 0.5279 & 2.7128 & 0.1761 & Benign & Benign \\
\hline 29 & Female & 35 & Breast & 5.2871 & 0.2381 & 3.1829 & 0.0301 & $\begin{array}{l}\text { Low grade } \\
\text { Malignancy }\end{array}$ & Benign \\
\hline 30 & Female & 41 & Chest & 4.5382 & 0.2473 & 3.0031 & 0.1383 & Benign & Benign \\
\hline 31 & Male & 50 & Cheek & 8.7812 & 0.3482 & 2.4932 & 0.0762 & Malignant & $\mathrm{BCC}$ \\
\hline 32 & Male & 61 & Cheek & 6.8231 & 0.4872 & 3.0045 & 0.0392 & $\begin{array}{l}\text { Low grade } \\
\text { Malignancy }\end{array}$ & SCC \\
\hline 33 & Male & 42 & Cheek & 7.5237 & 0.2367 & 2.4832 & 0.1289 & Malignant & SCC \\
\hline 34 & Male & 63 & Shoulder & 12.3287 & 0.4287 & 3.2761 & 0.2313 & Malignant & SCC \\
\hline
\end{tabular}


Table 1 Results of the $\mathbf{5 0}$ cases (Continued)

\begin{tabular}{|c|c|c|c|c|c|c|c|c|c|}
\hline 35 & Female & 39 & Cheek & 3.3231 & 0.1293 & 2.0213 & 0.0092 & Benign & Benign \\
\hline 36 & Male & 53 & Forearm & 10.2382 & 0.3981 & 4.2619 & 0.0312 & Malignant & SCC \\
\hline 37 & Male & 38 & Cheek & 11.2621 & 0.2761 & 3.0123 & 0.0927 & Malignant & $\mathrm{BCC}$ \\
\hline 38 & Male & 43 & Cheek & 5.9127 & 0.3327 & 2.0128 & 0.0327 & $\begin{array}{l}\text { Low grade } \\
\text { Malignancy }\end{array}$ & SCC \\
\hline 39 & Female & 29 & Cheek & 4.1281 & 0.0912 & 2.5321 & 0.0029 & Benign & Benign \\
\hline 40 & Female & 48 & Cheek & 6.2632 & 0.2642 & 2.9327 & 0.1234 & $\begin{array}{l}\text { Low grade } \\
\text { Malignancy }\end{array}$ & SCC \\
\hline 41 & Male & 45 & Cheek & 9.4753 & 0.3424 & 3.4842 & 0.2013 & Malignant & $\mathrm{BCC}$ \\
\hline 42 & Male & 38 & Arm & 10.3872 & 0.2345 & 2.9478 & 0.0231 & Malignant & SCC \\
\hline 43 & Male & 56 & Cheek & 12.3473 & 0.1283 & 2.8184 & 0.0281 & Malignant & SCC \\
\hline 44 & Male & 47 & Cheek & 18.4732 & 0.4328 & 3.045 & 0.0294 & Malignant & $\mathrm{BCC}$ \\
\hline 45 & Female & 34 & Chest & 6.3424 & 0.1384 & 3.3412 & 0.0634 & $\begin{array}{l}\text { Low grade } \\
\text { Malignancy }\end{array}$ & SCC \\
\hline 46 & Male & 44 & Leg & 13.4721 & 0.3714 & 3.1348 & 0.1392 & Malignant & $\mathrm{BCC}$ \\
\hline 47 & Male & 37 & Cheek & 6.0313 & 0.3591 & 3.2467 & 0.0482 & $\begin{array}{l}\text { Low grade } \\
\text { Malignancy }\end{array}$ & SCC \\
\hline 48 & Female & 46 & Cheek & 4.2485 & 0.1439 & 2.3411 & 0.0927 & $\begin{array}{l}\text { Low grade } \\
\text { Malignancy }\end{array}$ & Benign \\
\hline 49 & Male & 33 & Cheek & 4.4553 & 0.1943 & 3.0183 & 0.0046 & Benign & Benign \\
\hline 50 & Male & 58 & Cheek & 7.2384 & 0.3872 & 2.8274 & 0.06289 & Malignant & SCC \\
\hline
\end{tabular}

increment in the absorption coefficient of lesion over the absorption coefficient of normal healthy adjacent skin, then this lesion will be considered as a malignant lesion case.

Statistically, there are 36 cancerous patients (based on biopsy result) ware predicted positive by our test, these true positive (TP) patients cases represent $72 \%$ of all 50 cases.

While, Five non-cancerous lesion patients (based on biopsy result) ware predicted positive by our test, these false positive (FP) patients cases represent $10 \%$ of all 50 cases.

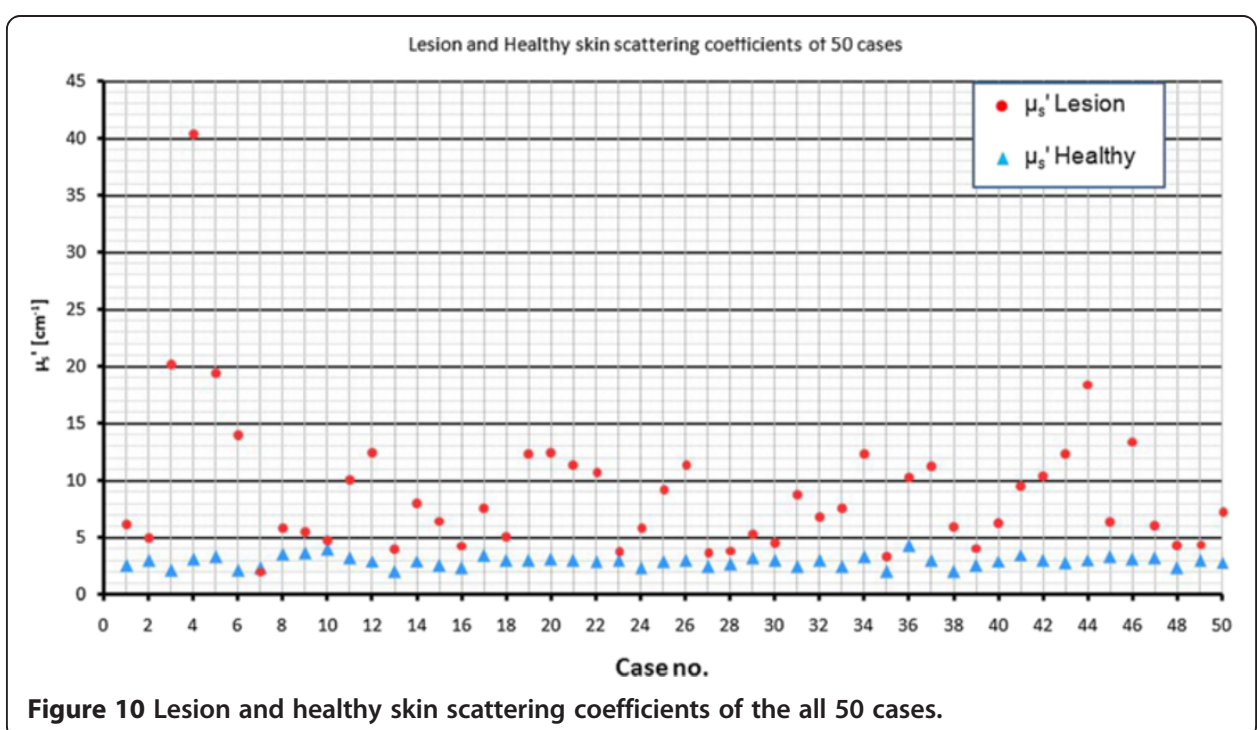




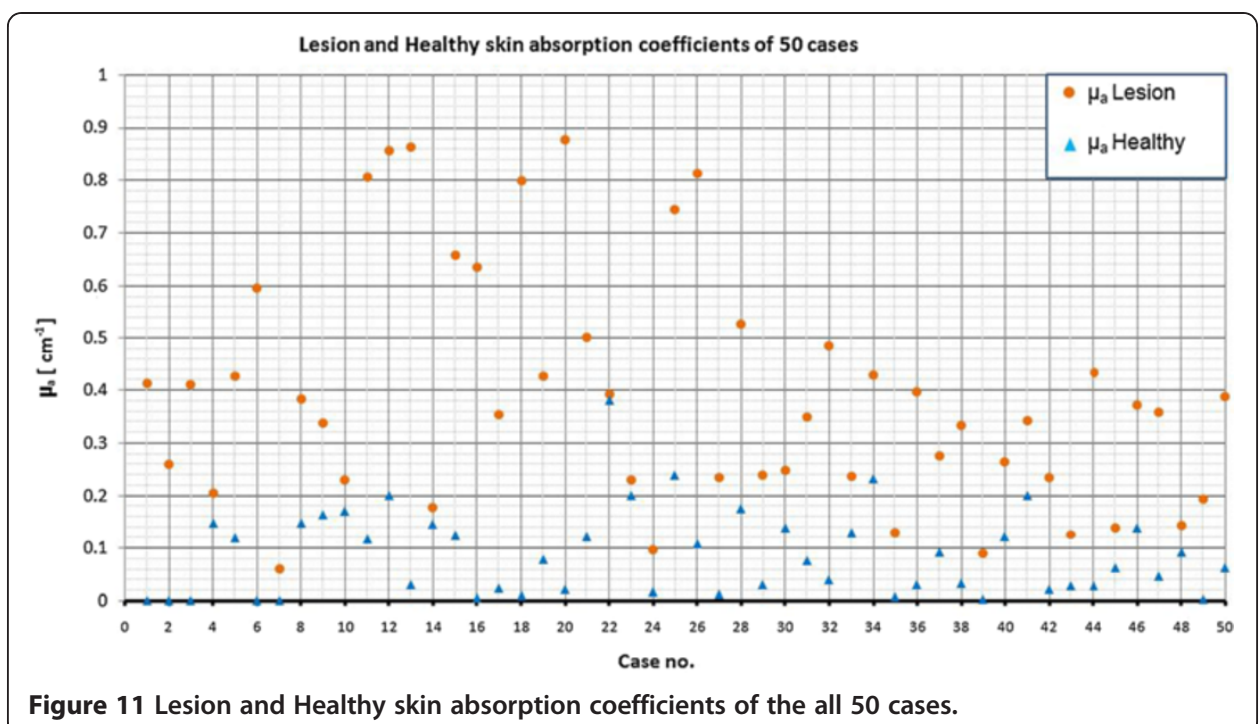

Nine non-cancerous lesion patients (based on biopsy result) ware predicted negative by our test, these true negative (TN) patients cases represent $18 \%$ of all 50 cases.

Finally, all patients predicted negative on our test ware diagnosed negative (based on biopsy result), therefore there is no false negative (FN) in our procedure. This was accomplished by choosing the precise $\left(1.8 \mathrm{~cm}^{-1}\right)$ threshold value.

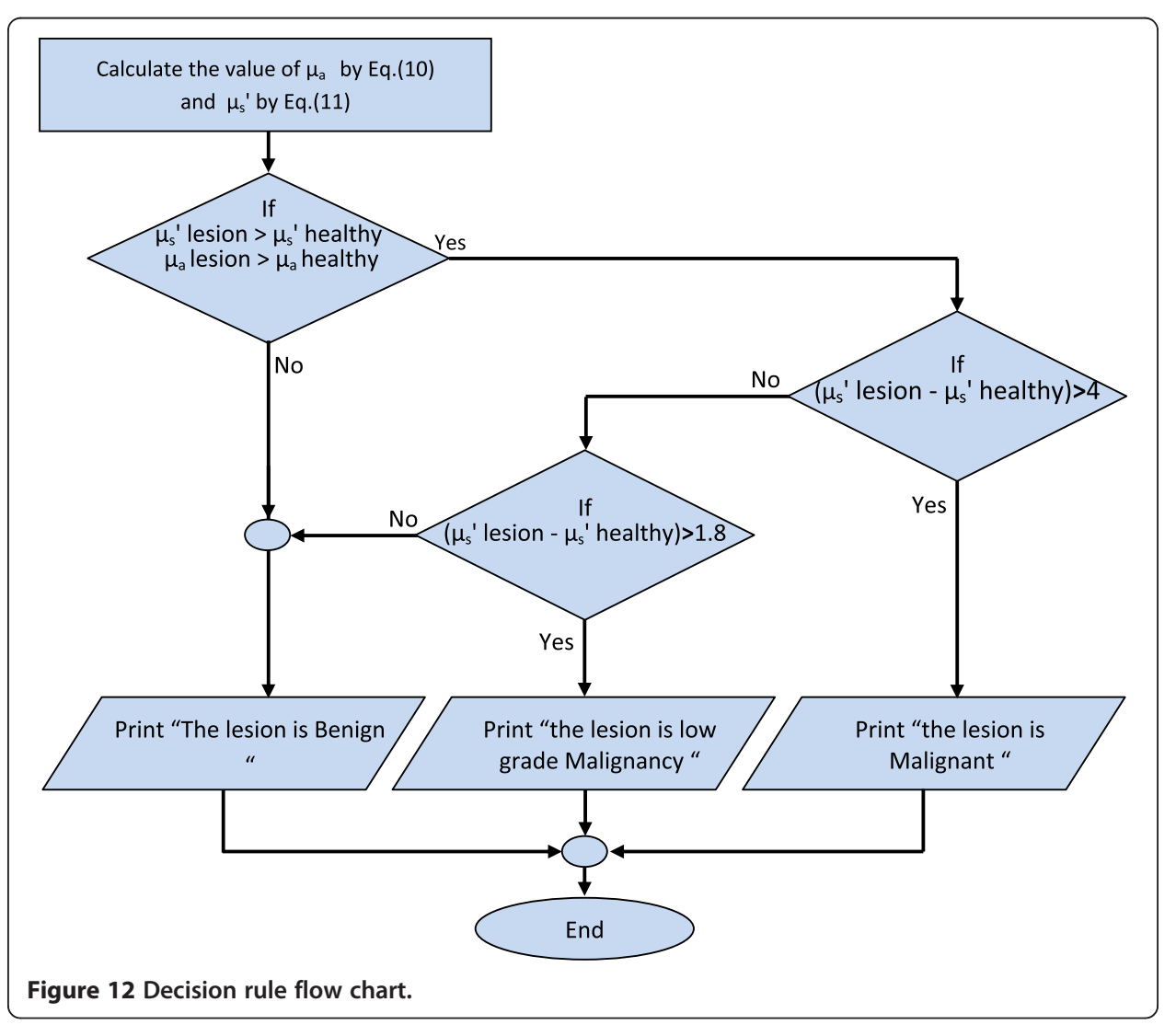


Table 2 Statistical results of the $\mathbf{5 0}$ cases

\begin{tabular}{lll}
\hline Statistic Item & Result & Notes \\
True positive (TP) & 36 & $72 \%$ of all 50 cases \\
False positive (FP) & 5 & $10 \%$ of all 50 cases \\
True negative (TN) & 9 & $18 \%$ of all 50 cases \\
False negative (FN) & Zero & $0.00 \%$ of all 50 cases \\
Specificity (TNR) & $64.62 \%$ & $=T N /(T N+F P)$ \\
$\begin{array}{l}\text { Sensitivity (TPR) } \\
\text { The positive prediction value (PPV)the proportion } \\
\text { of true positives out of all positive results }\end{array}$ & $100 \%$ & $=T P /(T P+F N)$ \\
$\begin{array}{l}\text { The Negative prediction value (NPV)the proportion } \\
\text { of true positives out of all positive results }\end{array}$ & $87.8 \%$ & $=T /(T P+F P)$ \\
Accuracy of our predictive measurements (ACC) & $100 \%$ & $=T N /(T N+F N)$ \\
& $90 \%$ & ACC $=(T P+T N) /(P+N) W h e r e ;$ \\
\hline
\end{tabular}

Proportion of 9 cases that tested negative (TN) of all the 14 patients that actually are negative (TN+FP) represent the Specificity (TNR) of our prediction which it $64.62 \%$ (With higher specificity, fewer suspected lesion patients are labeled as cancerous).

While, the Sensitivity (TPR) of our prediction results is 100\% (its represent the probability that our test is positive given that the patient has a cancer), this was accomplished by having no false negative (FN) cases. Table 2 shows the statistical results.

Patients cases no. $(13,16,18,29$, and 48) in Table 1 were predicted by the Matlab logical prediction as a "low grade malignancy", while the patients histological examination (biopsy result) show negative result for malignancy behavior, these false positive (FP) cases are appeared because the difference value between the reduced scattering coefficient of lesion and normal healthy adjacent skin being close to $1.8 \mathrm{~cm}^{-1}$.

Figure 13 shows the results of Matlab logical prediction with two lines of the scattering threshold that represent sensitivity zone of low grade malignancy, the yellow points represent the low grade malignancy cases, the red points represent the malignancy cases, while the blue points represent the benign lesion cases.

Low grade malignancy decision by our system is a critical decision, because it depend on the experience of the physicians to see the value of the difference between the normal and

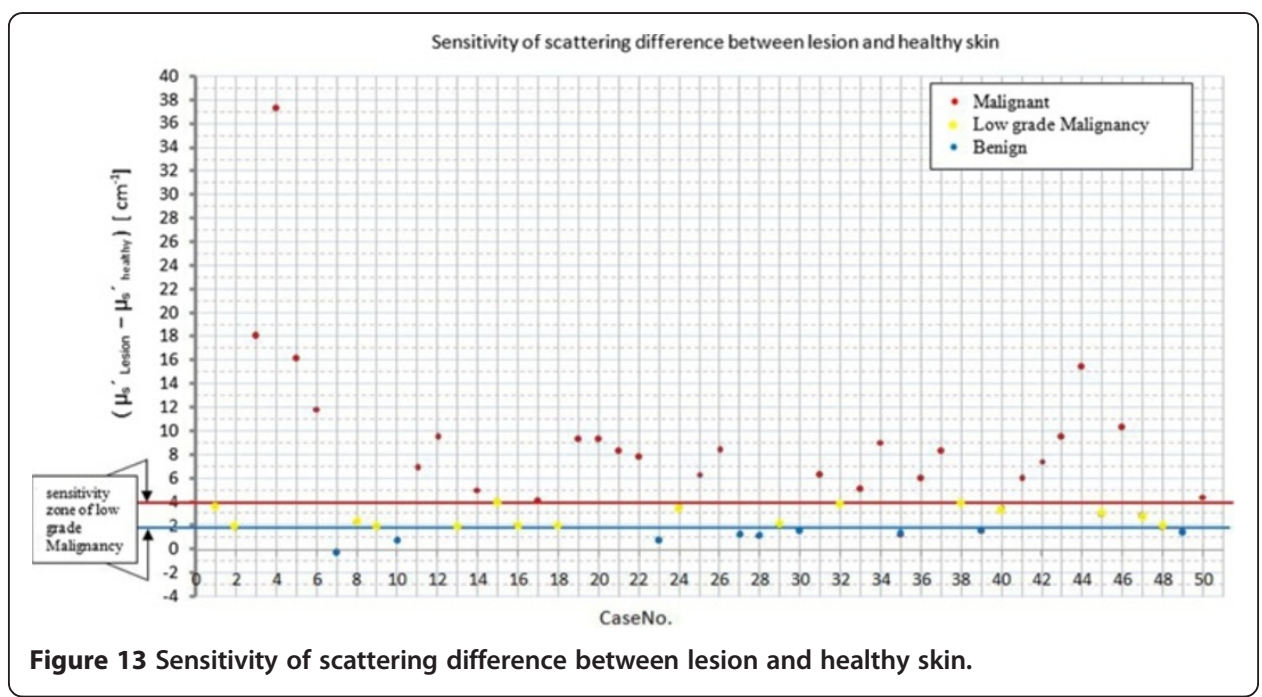


Table 3 The lesions that are on the cheek

\begin{tabular}{|c|c|c|c|c|c|c|c|c|c|c|}
\hline \multirow[t]{2}{*}{ No. } & \multirow[t]{2}{*}{$\begin{array}{l}\text { Case } \\
\text { No }\end{array}$} & \multicolumn{2}{|c|}{$\begin{array}{l}\text { Patient age } \\
\text { and Gender }\end{array}$} & \multirow[t]{2}{*}{$\begin{array}{l}\text { Lesion } \\
\text { Site }\end{array}$} & \multicolumn{2}{|c|}{$\begin{array}{l}\text { Skin lesion } \\
\text { optical } \\
\text { parameters }\end{array}$} & \multicolumn{2}{|c|}{$\begin{array}{l}\text { Healthy adjacent } \\
\text { skin optical } \\
\text { parameters }\end{array}$} & \multirow[t]{2}{*}{$\begin{array}{c}\text { Matlab } \\
\text { logical } \\
\text { prediction }\end{array}$} & \multirow{2}{*}{$\begin{array}{l}\text { Histological } \\
\text { diagnosis } \\
\text { (biopsy } \\
\text { results ) }\end{array}$} \\
\hline & & Gender & Age & & $\begin{array}{c}\mu_{\mathrm{s}}^{\prime} \\
{\left[\mathrm{cm}^{-1}\right]}\end{array}$ & $\underset{\left[\mathrm{cm}^{-1}\right]}{\mu_{\mathrm{a}}}$ & $\begin{array}{c}\mu_{\mathrm{s}}^{\prime} \\
{\left[\mathrm{cm}^{-1}\right]}\end{array}$ & $\begin{array}{c}\mu_{\mathrm{a}} \\
{\left[\mathrm{cm}^{-1}\right]}\end{array}$ & & \\
\hline 1 & 1 & Female & 30 & Cheek & 6.1033 & 0.4132 & 2.5565 & 0.0013 & $\begin{array}{l}\text { Low grade } \\
\text { Malignancy }\end{array}$ & SCC \\
\hline 2 & 3 & Male & 60 & Cheek & 20.1398 & 0.4108 & 2.1211 & 0.0016 & Malignant & SCC \\
\hline 3 & 4 & Male & 65 & Cheek & 40.4127 & 0.2058 & 3.1488 & 0.147 & Malignant & $\mathrm{BCC}$ \\
\hline 4 & 5 & Male & 53 & Cheek & 19.3786 & 0.4267 & 3.2852 & 0.1208 & Malignant & $\mathrm{BCC}$ \\
\hline 5 & 6 & Male & 72 & Cheek & 13.9541 & 0.5949 & 2.0975 & 0.0016 & Malignant & $\mathrm{BCC}$ \\
\hline 6 & 7 & Male & 42 & Cheek & 2.0559 & 0.0603 & 2.3434 & 0.0014 & Benign & Benign \\
\hline 7 & 8 & Male & 46 & Cheek & 5.787 & 0.3832 & 3.5257 & 0.1475 & $\begin{array}{l}\text { Low grade } \\
\text { Malignancy }\end{array}$ & SCC \\
\hline 8 & 9 & Male & 35 & Cheek & 5.4704 & 0.3384 & 3.6193 & 0.163 & $\begin{array}{l}\text { Low grade } \\
\text { Malignancy }\end{array}$ & SCC \\
\hline 9 & 12 & Male & 53 & Cheek & 12.453 & 0.857 & 2.9346 & 0.2001 & Malignant & SCC \\
\hline 10 & 14 & Male & 48 & Cheek & 7.963 & 0.1765 & 2.9361 & 0.1451 & Malignant & SCC \\
\hline 11 & 15 & Female & 47 & Cheek & 6.5169 & 0.6583 & 2.5561 & 0.1239 & $\begin{array}{l}\text { Low grade } \\
\text { Malignancy }\end{array}$ & SCC \\
\hline 12 & 16 & Male & 43 & Cheek & 4.3421 & 0.6342 & 2.3692 & 0.0056 & $\begin{array}{l}\text { Low grade } \\
\text { Malignancy }\end{array}$ & Benign \\
\hline 13 & 17 & Male & 38 & Cheek & 7.5231 & 0.3541 & 3.4321 & 0.0239 & Malignant & SCC \\
\hline 14 & 18 & Male & 58 & Cheek & 5.0145 & 0.8001 & 3.0189 & 0.0098 & $\begin{array}{l}\text { Low grade } \\
\text { Malignancy }\end{array}$ & Benign \\
\hline 15 & 19 & Male & 40 & Cheek & 12.341 & 0.4271 & 3.0341 & 0.0785 & Malignant & $\mathrm{BCC}$ \\
\hline 16 & 20 & Male & 46 & Cheek & 12.4521 & 0.8765 & 3.1452 & 0.0231 & Malignant & $\mathrm{BCC}$ \\
\hline 17 & 22 & Female & 45 & Cheek & 10.7432 & 0.3923 & 2.9313 & 0.3817 & Malignant & $\mathrm{BCC}$ \\
\hline 18 & 24 & Male & 51 & Cheek & 5.8123 & 0.0969 & 2.3847 & 0.0185 & $\begin{array}{l}\text { Low grade } \\
\text { Malignancy }\end{array}$ & SCC \\
\hline 19 & 25 & Male & 35 & Cheek & 9.1723 & 0.7453 & 2.8376 & 0.2387 & Malignant & SCC \\
\hline 20 & 26 & Female & 46 & Cheek & 11.3729 & 0.813 & 3.0062 & 0.1078 & Malignant & $\mathrm{BCC}$ \\
\hline 21 & 27 & Male & 42 & Cheek & 3.6791 & 0.2338 & 2.4312 & 0.0132 & Benign & Benign \\
\hline 22 & 31 & Male & 50 & Cheek & 8.7812 & 0.3482 & 2.4932 & 0.0762 & Malignant & $\mathrm{BCC}$ \\
\hline 23 & 32 & Male & 61 & Cheek & 6.8231 & 0.4872 & 3.0045 & 0.0392 & $\begin{array}{l}\text { Low grade } \\
\text { Malignancy }\end{array}$ & SCC \\
\hline 24 & 33 & Male & 42 & Cheek & 7.5237 & 0.2367 & 2.4832 & 0.1289 & Malignant & SCC \\
\hline 25 & 35 & Female & 39 & Cheek & 3.3231 & 0.1293 & 2.0213 & 0.0092 & Benign & Benign \\
\hline 26 & 37 & Male & 38 & Cheek & 11.2621 & 0.2761 & 3.0123 & 0.0927 & Malignant & $\mathrm{BCC}$ \\
\hline 27 & 38 & Male & 43 & Cheek & 5.9127 & 0.3327 & 2.0128 & 0.0327 & $\begin{array}{l}\text { Low grade } \\
\text { Malignancy }\end{array}$ & SCC \\
\hline 28 & 39 & Female & 29 & Cheek & 4.1281 & 0.0912 & 2.5321 & 0.0029 & Benign & Benign \\
\hline 29 & 40 & Female & 48 & Cheek & 6.2632 & 0.2642 & 2.9327 & 0.1234 & $\begin{array}{l}\text { Low grade } \\
\text { Malignancy }\end{array}$ & SCC \\
\hline 30 & 41 & Male & 45 & Cheek & 9.4753 & 0.3424 & 3.4842 & 0.2013 & Malignant & $\mathrm{BCC}$ \\
\hline 31 & 43 & Male & 56 & Cheek & 12.3473 & 0.1283 & 2.8184 & 0.0281 & Malignant & SCC \\
\hline 32 & 44 & Male & 47 & Cheek & 18.4732 & 0.4328 & 3.045 & 0.0294 & Malignant & $\mathrm{BCC}$ \\
\hline 33 & 47 & Male & 37 & Cheek & 6.0313 & 0.3591 & 3.2467 & 0.0482 & $\begin{array}{l}\text { Low grade } \\
\text { Malignancy }\end{array}$ & SCC \\
\hline
\end{tabular}


Table 3 The lesions that are on the cheek (Continued)

\begin{tabular}{|c|c|c|c|c|c|c|c|c|c|c|}
\hline 34 & 48 & Female & 46 & Cheek & 4.2485 & 0.1439 & 2.3411 & 0.0927 & $\begin{array}{l}\text { Low grade } \\
\text { Malignancy }\end{array}$ & Benign \\
\hline 35 & 49 & Male & 33 & Cheek & 4.4553 & 0.1943 & 3.0183 & 0.0046 & Benign & Benign \\
\hline 36 & 50 & Male & 58 & Cheek & 7.2384 & 0.3872 & 2.8274 & 0.06289 & Malignant & SCC \\
\hline \multirow{2}{*}{\multicolumn{7}{|c|}{$\begin{array}{l}\text { The mean value of the reduced scattering coefficient } \\
\text { for the healthy cheek skin }\end{array}$}} & \multicolumn{4}{|l|}{100.988} \\
\hline & & & & & & & \multicolumn{4}{|l|}{2.8052222} \\
\hline
\end{tabular}

lesion optical properties, as shown in Figure 13. When the difference between normal and healthy of $\mu_{\mathrm{s}}$ ' is close to $4 \mathrm{~cm}^{-1}$ threshold value, the physician must expect the malignancy behavior of the tested lesion and send the patient to perform a histological examination to be sure about the diagnosis. While, if the difference between normal and healthy of $\mu_{\mathrm{s}}^{\prime}$ is close to $1.8 \mathrm{~cm}^{-1}$ threshold value, the physician must expect the benign behavior of the tested lesion.

The threshold value used to eliminate the false negative (FN) diagnosis, e.g. if we change the threshold (difference) value $1.8 \mathrm{~cm}^{-1}$ to be $1.9 \mathrm{~cm}^{-1}$, this will produce a false negative diagnosis in case no. (02).

\section{Conclusions}

Only the relative profile of the diffuse reflectance was used for the extraction of optical properties, which made the device insensitive to variations of some system parameters such as intensity of the laser source.

The accuracy of Matlab logical prediction result depends on the image analysis and fitting accuracy to obtain optical properties of lesion and adjacent healthy skins, These results in turns depend on many factors such as the light source wavelength, resolution of CCD camera, and the procedure of estimating the center of the circles and determining the $\Delta \mathrm{x}$ shift, as well as the chosen $\mu_{\mathrm{s}}^{\prime}$ threshold value.

The overall accuracy of a our predictive measurements is $90 \%$ which represent the degree of closeness of our predictive measurements to the actual (true) diagnoses of suspected lesion, see Table 2.

The common site of SCC and BCC is on the face, therefore it was important to measure the accuracy of the method with respect to the lesion site, the accuracy of the measurements was $91.6 \%$ for all lesions that are on the cheek, Table 3. The mean value of the reduced scattering coefficient for the healthy cheek skin is $2.8 \mathrm{~cm}^{-1}$, that have the statistical variance of 0.1842 , and the standard deviation of $0.4292 \mathrm{~cm}^{-1}$.

\section{Abbreviations}

OIDR: Oblique Incidence Diffuse Reflectance; SCC: Squamous Cell Carcinomas; BCC: Basal Cell Carcinomas;

CCD: Charged Couple Device; MOH: Ministry of Health; NA: Natural Aperture; UV: Ultra Violate; IR: Infra Red.

Competing interests

The authors declare that they have no competing interests.

\section{Authors' contributions}

AMA obtained funding for the study, design and implementation the OIDR setup, performing the experimental work programming the engineering and statistical calculations by Matlab, interpretation of analyzed data, editing, drafting and finalizing the manuscript. MSD supervised the design of OIDR setup, advice the engineering and scientific bases of the research, interpretation of analyzed data, coordinated all the work, drafting and finalizing the manuscript. MKT prepared and selected the patients who are under our study, coordinated the hospital acceptance for the patients 
testing by our system, follow up the histological diagnosis of the selected patients, advice the dermatological information of the study, drafting and finalizing the manuscript. FAZ advice the histological information of the study, coordinated all work, drafting and finalizing the manuscript. All authors read and approved the final manuscript.

\section{Acknowledgements}

We would like to thanks Mr. Husam Shaker Al-Yasiry, general manger of Marifa Medical Co. Ltd. (www.mmc-iq.com), for his donate the CCD camera and Laser instruments. Thanks to team of Marjan Teaching Hospital Consultant Section for assistance in coordination of patients diagnosis.

\section{Author details}

${ }^{1}$ College of Engineering, Medical Engineering Department, Al-Nahrain University, Baghdad, Iraq. ${ }^{2}$ College of Medicine, Dermatology Department, Babylon university, Babylon, Iraq.

Received: 29 June 2012 Accepted: 13 November 2012

Published: 26 November 2012

\section{References}

1. American Cancer Society website: Melanoma and Non-melanoma Skin Cancer. http://www.cancer.org (accessed May 13th 2011).

2. Kong SG, Martin ME, Tuan V-D: "Hyperspectral fluorescence imaging for mouse skin tumor detection". ETRI J 2006, 28:Number 6.

3. Wang $L H$, Jacques $S L$ : "Source of error in calculation of optical diffuse reflectance from turbid media using diffusion theory". Compute Methods Programs Biomed 2000, 61(3):163-170.

4. Valery V: Tuchin, "Tissue optics: light scattering methods and instruments for medical diagnosis ". 2nd edition. USA: Washington; 2007.

5. Wang L-H, Jacques SL: "Use of a laser beam with an oblique angle of incidence to measure the reduced scattering coefficient of a turbid medium". Applied Optic 1996, 34:2362-2366.

6. Marquez G, Wang LH: "White light oblique incidence reflectometer for measuring absorption and reduced scattering spectra of tissue-like Turbid media". Opt Exp v 1997, 1:454-460.

7. Vinay K, Abbas AK, Nelson F, Richard M: "Robbins, Basic Pathology", 8th edition. USA: Saunders/Elsevier company; 2007. ISBN 1-4160-2973-7.

8. Lin S-P, Wang L, Jacques SL, Tittel FK: " Measurement of tissue optical properties by the use of oblique-incidence optical fiber reflectometry". Appl Opt 1997, 36:136-143.

9. Hua Jiang W, Da X, Bo Hua H, Huai Min G, Guo Yong W, Xue Mei C: "Using an oblique incident laser beam to measure the optical properties of stomach mucosa/submucosa tissue“. UK: BioMed Central Ltd, BMC Gastroenterology; 2009.

10. Zonios G, Bykowsky J, Kollias N: "Skin melanin, hemoglobin, and light scattering properties can be quantitatively assessed in vivo using diffuse reflectance spectroscopy". J Invest Dermatol 2001, 117(issue. 6):1452-1457.

11. Niemz MH: "Laser Tissue Interaction". Berlin: Springer-Verlage; 2007.

12. Chen $Y$, Cao L, Sun L: "Asymmetric diffusion model for oblique incidence reflectometry " Chinese Optics Scientific Letters". Beijing, China: Tsinghua University; 2011.

\section{Submit your next manuscript to BioMed Central and take full advantage of:}

- Convenient online submission

- Thorough peer review

- No space constraints or color figure charges

- Immediate publication on acceptance

- Inclusion in PubMed, CAS, Scopus and Google Scholar

- Research which is freely available for redistribution 